\title{
ELEMENTAL CONTENT IN GRASSLAND OF SEMIARID ZONES: EFFECT OF TOPOGRAPHIC POSITION AND BOTANICAL COMPOSITION
}

B. R. Vazquez de Aldana, A. Garcia Ciudad, E. P. Corona, and B. Garcia Criado

Instituto de Recursos Naturales y Agrobiologia (CSIC), Apartado 257, 37071 Salamanca, SPAIN

ABSTRACT: Elemental composition (N, P, K, Ca, $\mathrm{Mg}, \mathrm{Na}, \mathrm{Mn}, \mathrm{Fe}, \mathrm{Cu}$, and $\mathrm{Zn}$ ) was studied in semi-natural grassland communities of the province of Salamanca (Central-Western Spain) under the effect of a topographical gradient (two differentiated slope positions: upper zone and lower zone) and for the main botanical groups forming these communities (grasses, legumes, and other families). In the upper positions where the proportion in weight of legumes and other families is greater than in the lower ones, the $\mathrm{P}, \mathrm{Ca}, \mathrm{Fe}$, and $\mathrm{Cu}$ concentrations were higher than in the lower. For elements like $\mathrm{N}, \mathrm{Mg}$, and $\mathrm{Zn}$, the zonal difference in the grass was not significant, since this was counteracted by the greater nutrient content of the lower zones and a dilution effect due to the greater production of biomass in that zone. The mean value of the $\mathrm{K}:(\mathrm{Ca}+\mathrm{Mg})$ ratio in the grass was significantly lower $(\mathrm{P}<0.05)$ in the upper zone than in the lower one, and all the samples were lower than the critical value for livestock [2.2]. The highest Ca:P ratio values were also found in the lower zone, with the legumes showing the highest values.

Considering the upper and lower zones together, the number of significant correlations between the bioelements was higher for the gramineae group; $\mathrm{N}, \mathrm{K}$, and $\mathrm{Mg}$ being the elements forming the most correlations within that family. The correlation between $\mathrm{Ca}$ and $\mathrm{Mg}$ concentrations is noteworthy, appearing in all the cases under consideration. Differentiation by zones gave a lower number of 
significant correlations than when the upper and lower zones were considered together.

\section{INTRODUCTION}

The "dehesa" zone occupies a great part of the province of Salamanca (Central-Western Spain). This terrain is characterized by the presence of scarce tree-canopy and a large open spaces with shrub-like and herbaceous strata serving as pastureland for livestock.

Plants, one of the main components of these communities, have a capacity for response in the face of different agents. Thus, the chemical composition of the grass depends on various factors: the type of soil, botanical composition, phenological phase, climatic and seasonal conditions and the use to which the land is put. These aspects have been reviewed by several authors $(2,6,14,21)$; however, little attention has been paid to the effect of topographical position on these variations.

Just as important as the nutrient concentrations in the grass are the relationships that can be established between these nutrient levels and those of other components. The interpretation of such relationships is complex, since the nutrients interact among themselves from the very moment of their absorption. Nonetheless, an analysis of the correlation between the concentrations can be a first step towards understanding these relationships. Certain particular aspects which can affect the correlations between elements have been studied by several authors $(9,11,12,15)$.

The present work studies the effects of taxonomic group and topographical gradient on the concentration of the nutrients $\mathrm{N}, \mathrm{P}, \mathrm{K}, \mathrm{Ca}, \mathrm{Mg}, \mathrm{Na}, \mathrm{Mn}, \mathrm{Fe}, \mathrm{Cu}$, and $\mathrm{Zn}$, and the $\mathrm{Ca}: \mathrm{P}$ and $\mathrm{K}:(\mathrm{Ca}+\mathrm{Mg})$ ratios in semi-natural grassland communities and attempts to determine the possible correlations between these mineral elements, taking into account both effects.

\section{MATERIALS AND METHODS}

The samples analyzed were collected from 30 selected slopes of pasture communities in the "dehesa" zone of the province of Salamanca (CW Spain) during June 1987. In this area the annual rainfall during the year studied was 592 
$\mathrm{mm}$ with the following distribution: $145 \mathrm{mn}$ in autumn; $185 \mathrm{~mm}$ in winter; 121 $\mathrm{mm}$ in spring and 141 in summer. The average monthly temperature ranged between $1.7^{\circ} \mathrm{C}$ in January and $20.8^{\circ} \mathrm{C}$ in August $\left(11^{\circ} \mathrm{C}\right.$ annual mean).

On each slope, samples of plant biomass were taken from two topographically differentiated zones: an eroded zone (upper part) and an accumulation zone (lower part) during the flowering-fructification phase. The samples were collected in duplicate cutting in each case the plant material contained in three randomly chosen $0.5 \mathrm{~m}$ squares. In one of the duplicates three large taxonomic groups were separated manually: grasses, legumes and other families, the other was considered as such. The four samples obtained from each place were dried in an oven at $60^{\circ} \mathrm{C}$; the proportions of dry matter were determined and then ground in a mill with a 0.5-mm mesh sieve.

Potassium, $\mathrm{Ca}, \mathrm{Mg}, \mathrm{Na}, \mathrm{Mn}, \mathrm{Fe}, \mathrm{Cu}$, and $\mathrm{Zn}$ concentrations were determined by atomic absorption spectrophotometry, $\mathrm{P}$ by colorimetry using the vanadomolybdophosphoric yellow method, and $\mathrm{N}$ by the Kjeldhal method (5). The Ca:P and $\mathrm{K}:(\mathrm{Ca}+\mathrm{Mg})$ ratios, expressed on an equivalent basis, were calculated.

Analysis of variance (ANOVA, LSD at $\mathrm{P}<0.05$ ) was used to compare zones and families for each nutrient. Simple correlation analysis was applied to the concentrations of the above elements for herbage, grasses, legumes and other families, considering the two slope zones together and each one separately.

\section{RESULTS AND DISCUSSION}

The mean concentration of the nutrient elements analyzed is show schematically in Figure 1, and the effect of both the taxonomic group and the slope position (Tables 1 and 2) can be observed. It can also be seen that within the grasses, the nutrient concentration for both zones had a similar distribution, although in different ranges.

In general, the lower zones are more fertile, maintaining greater soil humidity and being richer in nutrients, thus making the mineral concentration of the grass higher; however, due to a dilution effect caused by the greater production of biomass in these zones, the opposite phenomenon may occur, thus decreasing the nutrient concentration in the grass. 


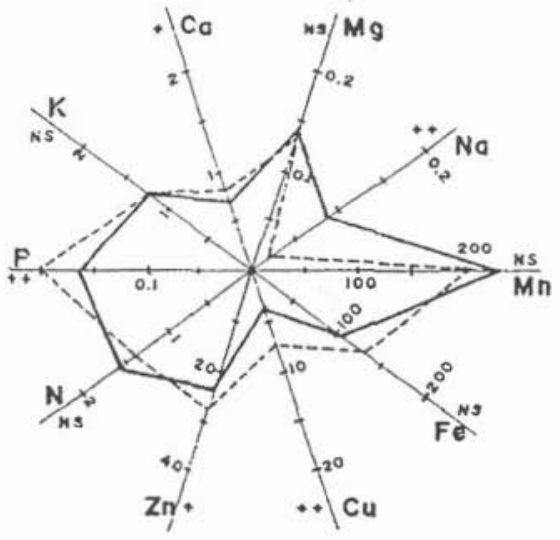

HERBAGE

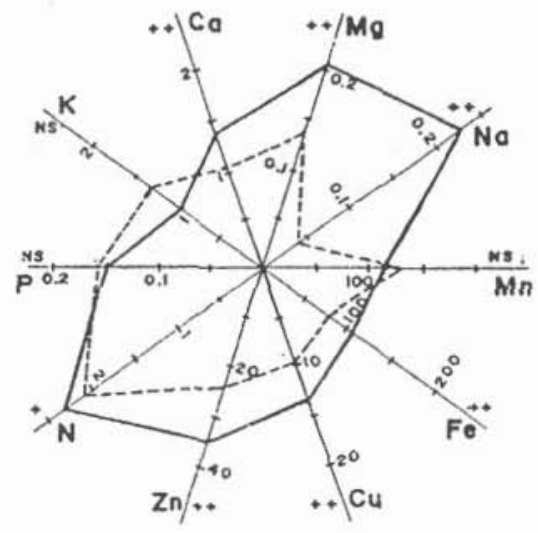

LEGUMES

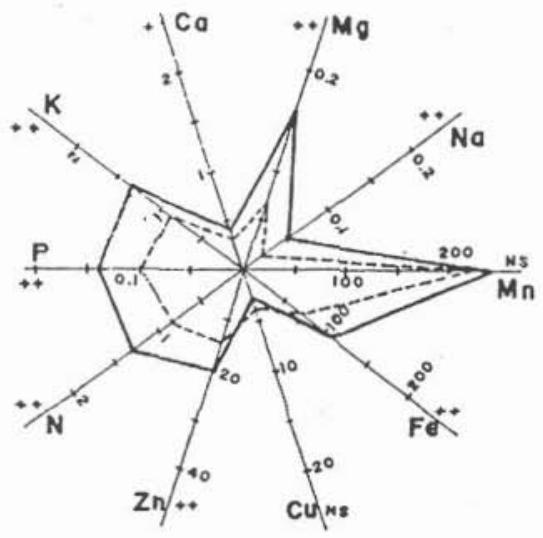

GRASSES

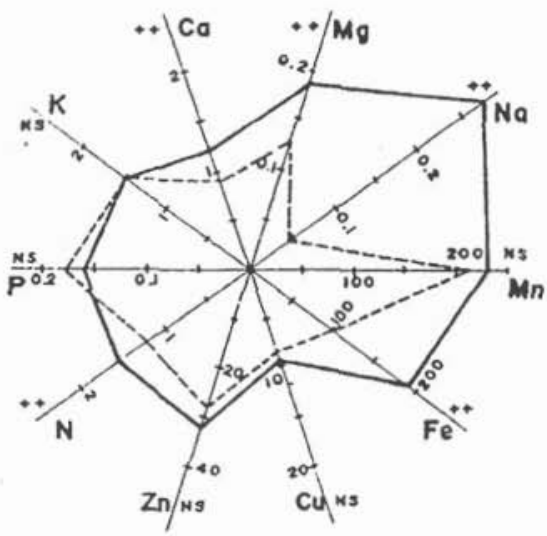

OTHER FAMILIES

--- upper zone lower zone

-.+ Significance at $P<0.05, P<0.01$ respectively NS non significance

FIGURE 1: Mean nutrient concentrations in grass and botanical groups in the upper and lower zones of slope. 
TABLE 1. Macronutrient concentrations in nerbage and botanical components in two positions of slope.

\begin{tabular}{|c|c|c|c|c|c|c|}
\hline \multirow{2}{*}{$\begin{array}{l}\text { HERBAGE } \\
\text { upper m }\end{array}$} & $\mathrm{N}(\%)$ & $\mathbf{P}(\%)$ & $\mathrm{K}(\%)$ & $\mathrm{Ca}(\%)$ & $\mathrm{Mg}(\%)$ & $\mathrm{Na}(\%)$ \\
\hline & 1.08 & 0.12 & 0.80 & 0.39 & 0.10 & 0.01 \\
\hline zone $\mathrm{M}$ & 2.06 & 0.32 & 2.80 & 1.40 & 0.30 & 0.06 \\
\hline $\mathrm{x}$ & 1.46 & 0.20 & 1.32 & 0.73 & 0.13 & 0.02 \\
\hline$\hat{\mathrm{CV}}$ & 20.3 & 25.0 & 33.3 & 28.0 & 30.8 & 50.0 \\
\hline lower $\mathrm{m}$ & 1.19 & 0.09 & 0.74 & 0.29 & 0.09 & 0.01 \\
\hline zone $\mathrm{M}$ & 2.09 & 0.23 & 2.00 & 1.10 & 0.20 & 0.25 \\
\hline $\mathrm{x}$ & 1.56 & 0.17 & 1.35 & 0.61 & 0.14 & 0.09 \\
\hline $\mathrm{CV}$ & 16.2 & 17.7 & 24.4 & 32.4 & 21.4 & 77.8 \\
\hline LSD $(\mathrm{P}<0.05)$ & NS & 0.02 & NS & 0.10 & NS & 0.03 \\
\hline \multicolumn{7}{|l|}{ GRASSES } \\
\hline upper $\mathrm{m}$ & 0.58 & 0.04 & 0.40 & 0.14 & 0.05 & 0.01 \\
\hline zone $\mathrm{M}$ & 1.33 & 0.17 & 1.40 & 0.43 & 0.10 & 0.04 \\
\hline $\mathrm{x}$ & 0.91 & 0.10 & 0.87 & 0.28 & 0.07 & 0.01 \\
\hline $\mathrm{CV}$ & 20.4 & 40.0 & 29.9 & 29.6 & 14.3 & 57.1 \\
\hline lower $\mathrm{m}$ & 1.05 & 0.07 & 0.70 & 0.18 & 0.06 & 0.01 \\
\hline zone M & 1.94 & 0.21 & 2.10 & 0.60 & 0.14 & 0.23 \\
\hline $\mathrm{x}$ & 1.37 & 0.14 & 1.39 & 0.33 & 0.10 & 0.05 \\
\hline $\mathrm{CV}$ & 15.0 & 28.6 & 23.7 & 27.5 & 75.0 & 100 \\
\hline LSD $(\mathrm{P}<0.05)$ & 0.11 & 0.02 & 0.16 & 0.05 & 0.01 & 0.02 \\
\hline \multicolumn{7}{|l|}{ LEGUMES } \\
\hline upper m & 1.61 & 0.09 & 0.54 & 0.45 & 0.08 & 0.02 \\
\hline zone M & 2.65 & 0.26 & 1.70 & 1.70 & 0.30 & 0.28 \\
\hline $\mathrm{x}$ & 2.07 & 0.16 & 1.13 & 0.88 & 0.14 & 0.04 \\
\hline $\mathrm{CV}$ & 13.5 & 25.0 & 28.3 & 26.5 & 28.6 & 125 \\
\hline lower $\mathrm{m}$ & 1.66 & 0.09 & 0.29 & 0.89 & O.II & 0.03 \\
\hline zone $\mathrm{M}$ & 3.01 & 0.28 & 1.70 & 2.10 & 0.45 & 0.68 \\
\hline $\mathrm{x}$ & 2.28 & 0.15 & 0.98 & 1.43 & 0.22 & 0.23 \\
\hline CV & 15.9 & 33.3 & 37.8 & 23.6 & 40.9 & 78.3 \\
\hline LSD $(P<0.05)$ & 0.12 & NS & NS & 0.15 & 0.04 & 0.07 \\
\hline \multicolumn{7}{|c|}{ OTHER FAMILIES } \\
\hline upper $\mathrm{m}$ & 0.87 & 0.09 & 0.72 & 0.38 & 0.08 & 0.02 \\
\hline zone $\mathrm{M}$ & 1.70 & 0.32 & 2.40 & 1.40 & 0.25 & 0.33 \\
\hline$x$ & 1.18 & 0.18 & 1.50 & 0.79 & 0.13 & 0.04 \\
\hline $\mathrm{CV}$ & 16.5 & 38.9 & 30.0 & 27.1 & 23.1 & 150 \\
\hline lower $\mathrm{m}$ & 1.12 & 0.05 & 0.54 & 0.41 & 0.08 & 0.05 \\
\hline zone M & 2.12 & 0.28 & 2.20 & 1.60 & 0.35 & 0.93 \\
\hline $\mathrm{x}$ & 1.52 & 0.16 & 1.49 & 0.97 & 0.19 & 0.31 \\
\hline CV & 17.2 & 31.3 & 29.5 & 24.1 & 31.6 & 77.4 \\
\hline LSD $(\mathrm{P}<0.05)$ & 0.17 & NS & NS & 0.12 & 0.03 & 0.09 \\
\hline LSD fam. & 0.11 & 0.02 & 0.14 & 0.10 & 0.02 & 0.06 \\
\hline zones & 0.15 & NS & NS & 0.13 & 0.02 & 0.05 \\
\hline
\end{tabular}

$\dot{\mathrm{m}}=$ minimum value, $M=$ maximum value, $\mathrm{x}=$ mean value; $C V=$ coefficient of variation. 
TABLE 2. Micronutrient concentrations in herbage and botanical components in two positions of slope.

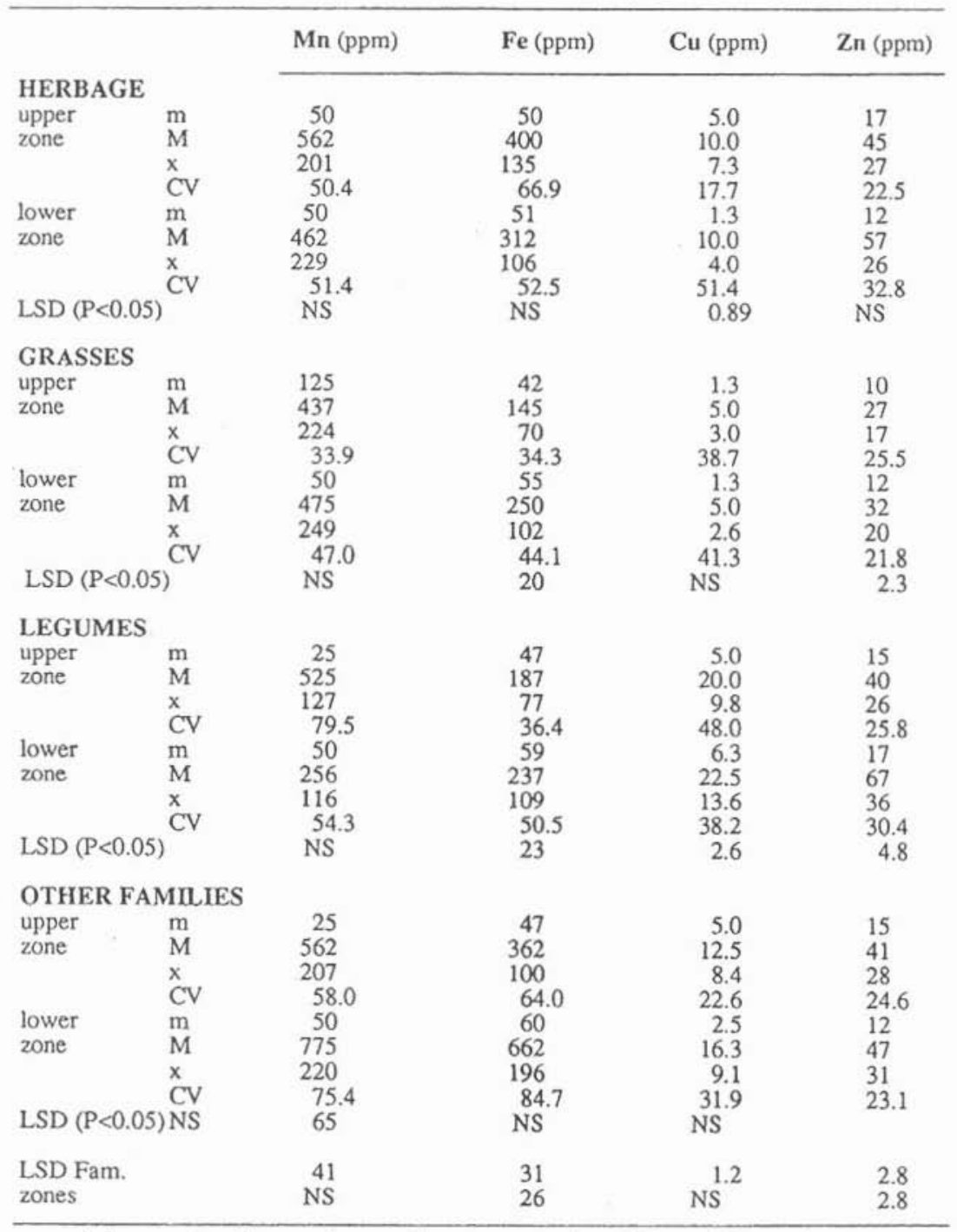

$\mathrm{m}=$ minimum value, $\mathrm{M}=$ maximum value, $\mathrm{x}=$ mean value; $\mathrm{CV}=$ coefficient of variation. 
Nitrogen: Zonal differences in $\mathrm{N}$ levels were patent in the three groups of families, with a higher concentration in the lower zones, where the soil is richer in nutrients. In herbage the difference between zones was not significant $(P>0.05)$, probably owing to the effects of greater fertility in the lower zones and a greater proportion of legumes and other families, that are richer in $\mathrm{N}$, in the upper zone (3). The nitrogen level in legumes tended to be higher than in grasses, as long as the level of $\mathrm{N}$ available was low, because at high $\mathrm{N}$ levels this difference between families may be compensated (22).

Phosphorus: The difference between zones was not notable, being significant only in grasses $(\mathrm{P}<0.05)$ and in herbage with opposite tendencies. Phosphorus concentration was similar in grasses and legumes samples in the lower zone, while in the upper one it was notably higher for legumes than for grasses, which is in agreement with Whitehead (22) who pointed out that the presence of legumes in a grass sward can increase the P content of the grass. The mean values of other families were higher than those of legumes $(0.18$ and $0.16 \%$ in the upper and lower zones, respectively).

The grass can be considered deficient for livestock, particularly in the low zone. These deficiencies have already been reported in other works (10).

Potassium: The mean $\mathrm{K}$ values were similar in both zones; there were significant differences only in the case of grasses, and the low zone (1.39\%) was richer than the upper one $(0.87 \%)$. The families of grasses and legumes had a similar $\mathrm{K}$ content, as expected, since according to Fleming (6) the quantity of $\mathrm{K}$ in the plant depends mainly on the level available in the soil while grasses may have higher or lower $\mathrm{K}$ concentrations than legumes. However, the mean contents in other families were notably higher (Table 1). It is not surprising that the $\mathrm{K}$ content of grass samples is above the levels required in animal nutrition, since the $\mathrm{K}$ requirements of the plant clearly exceed those of livestock (21).

Calcium: For this element, significant differences were found between the zones $(\mathrm{P}<0.05)$ in the botanical fractions considered separately (Figure 1$)$. The lower position was richer in $\mathrm{Ca}$, the grasses having a clearly lower level than the legumes and other families. Nevertheless, the mean value for herbage in the upper zones $(0.73 \%)$ was higher than in the lower zones $(0.61 \%)$, since the families that are richer in this element predominate in the high position (3). In general, the grass 
had $\mathrm{Ca}$ levels above the minimum required for animal nutrition $(0.35 \%)$, and is thus adequate for the diet of livestock.

Magnesium: $\mathrm{Mg}$ concentration was found to vary with topographical position in much the same way as that of $\mathrm{N}$ in the different families, with higher mean values in the low zones, produced by a strong leaching of this element. In the grass the difference between zones was not significant $(\mathrm{P}>0.05)$, since the effects of greater fertility in the lower zones is compensated by a higher proportion of legumes and "others", richer in $\mathrm{Mg}$ (13), on the upper part of the slope.

A few samples exceeded the levels required in animal nutrition $(0.20 \%)$, such that the grass can be considered deficient for livestock. Previous works (10) have already pointed out these deficiencies, which in fact are worldwide (14).

Sodium: The differences between zones in Na concentrations were noteworthy. The topographical effect had the greatest influence observed with respect to this nutrient, due to its greater solubility and easy leaching from the eroded zone (upper) to the accumulation zone (lower). This difference was found for both herbage and the botanical fractions (Figure 1), but was more pronounced in the group of "others" where the mean value for the low zone $(0.31 \%)$ was up to eight times higher than that of the upper part $(0.04 \%)$. This is due to a greater availability of $\mathrm{Na}$ in the lower position and to the great variability in the $\mathrm{Na}$ content of grass species (14). Plants usually have a low Na content with respect to the nutritional requeriments of ruminants (1). It is not surprising that no grass sample from the high zone and only $40 \%$ of those from the lower part exceed the required levels for animal nutrition (0.06-0.10\%).

Manganese: Although the difference between zones was not significant for this nutrient $(\mathrm{P}>0.05)$, the mean value for grass in the lower part is higher (Table 2). This is due to the presence in that zone of a higher proportion of grasses which are generally richer in $\mathrm{Mn}$ (4), and a lower degree of soil aeration which can increase this effect (17). However, for legumes, the mean value in the upper zone was higher, although not significantly different $(\mathrm{P}>0.05)$ from the lower part, probably caused by the predominant species in these zones, given the wide variability of this element with respect to species (17).

Iron: Although the mean value of Fe concentration in grass was higher for the upper position, the difference between zones was not significant $(\mathrm{P}>0.05)$. Upon 
considering botanical groups, however, the zonal differences were significant in all the families (Table 2), with higher concentrations in the lower part of the slope. Copper: The Cu concentration was found to vary with topographical position in grass, with the same tendencies as in $\mathrm{Ca}$, influenced by the botanical composition. In the highest topographical zones with a predominance of the fractions of legumes and "others", clearly richer in $\mathrm{Cu}$ (7), the mean value was higher than in the lower parts. Zonal differences in the botanical fractions were only significant for legumes, with higher $\mathrm{Cu}$ concentrations in the lower zone. The grass samples could be deficient in $\mathrm{Cu}$ for livestock, especially in the lower position.

Zinc: The lower zones of the slopes tend toward higher concentrations of $\mathrm{Zn}$, although for grass the difference between zones was not significant (Table 2). This balance is possibly due to differences in content among the taxonomic groups and the different proportions of these groups in each zone (as occurred with $\mathrm{Mg}$ and $\mathrm{N}$ ). The $\mathrm{Zn}$ levels were similar for legumes and other families and are clearly superior to those of grasses, although Lamand (16) noted the opposite.

Ca:P and $K:(C a+M g)$ Ratios: When considering animal nutrition, it is important to keep in mind certain necessary mineral balances in the diet, such as $\mathrm{Ca}: \mathrm{P}$ and $\mathrm{K}:(\mathrm{Ca}+\mathrm{Mg})$, which when perturbed may lead to metabolic disorders in livestock.

Ca:P Ratio: The highest mean values of the Ca:P ratio (Table 3 ) appeared in legumes [10.3] and other families [6.7] of the lower zone, logically due to the fact that the $\mathrm{Ca}$ concentrations there are higher (Table1). The grasses samples showed considerably lower mean values [3.39 and 2.71 for the upper and lower zones, respectively]. For herbage there were no significant differences $(\mathrm{P}>0.05)$ between the zones, with a mean value of 3.9 in both parts.

The most adequate value for the Ca:P ratio in a diet for livestock growth lies within a range of 1.0 and 2.0, although according to McDowell (19), ruminants can actually tolerate a wider range, reaching values of 7.0 , particularly when the vitamin D status is high. Therefore, considering the levels in grass, the pastures studied can be said to lie within the tolerable range, although the legumes, considered seperately, show higher values.

$\underline{K}:(\mathrm{Ca}+\mathrm{Mg})$ Ratio: The mean value of this ratio in grass was significantly lower $(\mathrm{P}<0.05)$ in the upper zone [0.72] than in the lower one [0.88]. The grasses 
had highest values (Table 3), evidently due to the fact that $\mathrm{Ca}$ and $\mathrm{Mg}$ concentrations are lower in this group than in legumes and "others" (Table 1).

Low $\mathrm{Mg}$ concentrations in grass $(<0.02 \%)$ may induce grass tetany in ruminants. This disorder occurs most frequently in spring and autumn, especially when these seasons are cold and wet (13). Moreover, high $\mathrm{K}$ concentration in grass can reduce the quantity of $\mathrm{Mg}$ available, thereby increasing the risk of grass tetany $(13,18)$. Taking into account these effects, the risk can be said to be aggravated when the value of the $\mathrm{K}:(\mathrm{Ca}+\mathrm{Mg})$ ratio in the diet (expressed on equivalent basis) exceeds 2.2 .

In the samples studied, all the values for herbage and the botanical fractions (except one sample of grasses in the upper zone) were lower than the critical value.

\section{CORRELATIONS BETWEEN NUTRIENTS}

The significant correlations $(\mathrm{P}<0.05, \mathrm{P}<0.01)$ between the concentrations of the elements determinated are shown in Figure 2. Two aspects are considered, i) on the one hand, the effect of the botanical composition (grasses, legumes, other families and herbage) for the upper and lower zones together, and ii) on the other hand, the topographical position (high and low zones).

Effect of Botanical Composition: Considering the high and low zones together for grasses, legumes, other families and herbage, it is seen (Figure 2) that the number of correlations between the concentrations of elements is greater for grasses than for the rest of the groups. This difference was pointed out by Garcia (8) in a study on species of grasses and legumes in seminatural communities.

In the three taxonomic groups considered, and in grass, positive relationships can be established between $\mathrm{N}-\mathrm{Ca}, \mathrm{N}-\mathrm{Mg}, \mathrm{N}-\mathrm{Na}, \mathrm{N}-\mathrm{Zn}, \mathrm{Mg}-\mathrm{Na}$, and $\mathrm{Ca}-\mathrm{Mg}$. For this latter relationship, the high correlation coefficients were prominent: $r=0.63$, $\mathrm{P}<0.01$ (for grass); $\mathrm{r}=0.61, \mathrm{P}<0.01$ (for grasses); $\mathrm{r}=0.80, \mathrm{P}<0.01$ (for legumes) and $\mathrm{r}=0.56, \mathrm{P}<0.01$ (for other families). The negative relationship between $\mathrm{Mn}-\mathrm{Ca}$ appeared in all the groups considered, except in legumes, where it was also negative but not significant $(\mathrm{P}>0.05)$.

For grasses, $\mathrm{N}, \mathrm{K}$, and $\mathrm{Mg}$ showed the highest number of positive and significant correlations, and were associated with the rest of the elements, with the 
UPPER AND LOWER ZONES

GRASSES
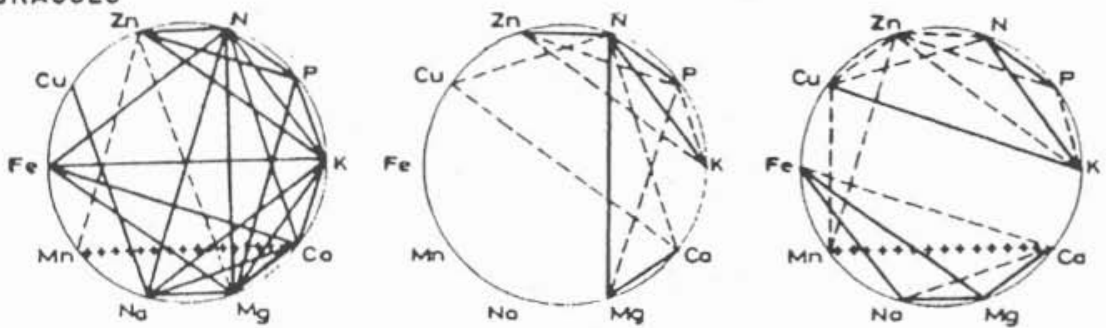

\section{LEGUMES}
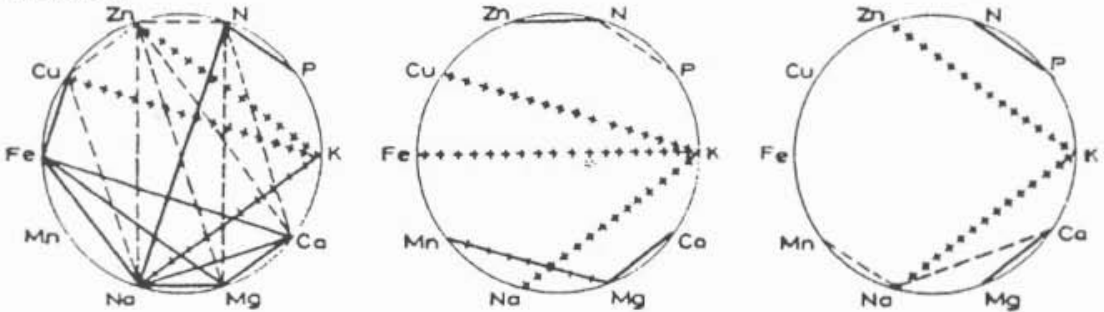

OTHER FAMILIES
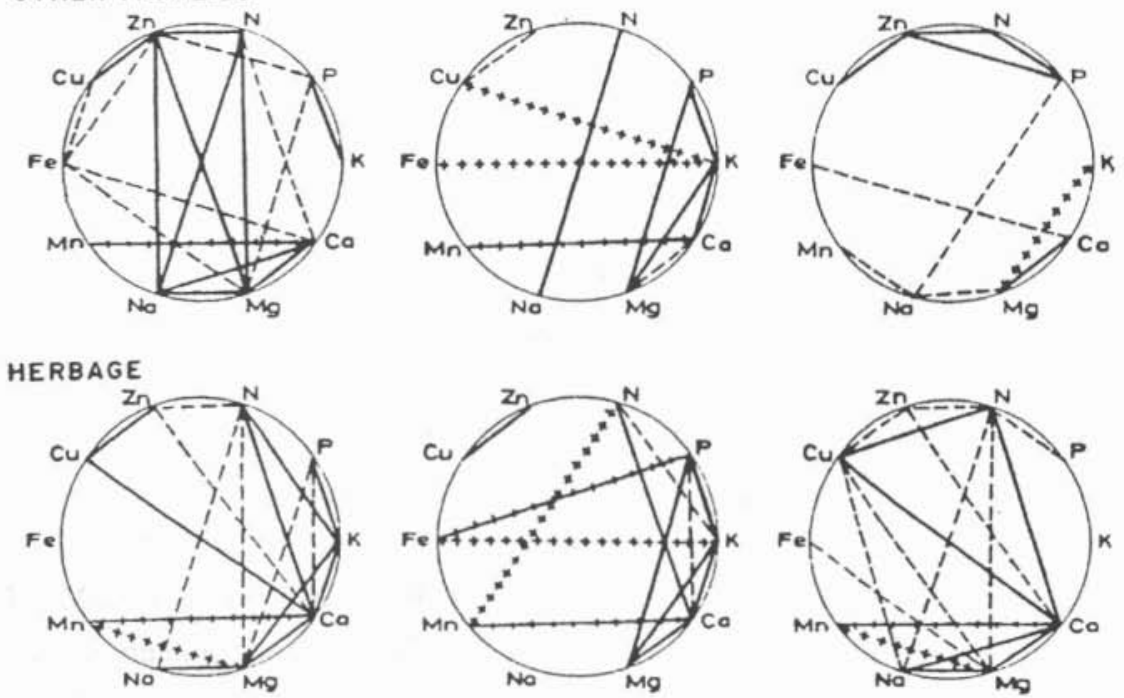

Sign and significance level

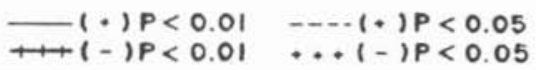

FIGURE 2: Significant relationships between bioelements under the effects of topography and botanical composition. 
exception of $\mathrm{Cu}$ and $\mathrm{Mn}$. Of note are the high coefficients between $\mathrm{N}-\mathrm{P}(\mathrm{r}=0.66$, $\mathrm{P}<0.01), \mathrm{N}-\mathrm{K}(\mathrm{r}=0.77, \mathrm{P}<0.01)$, and $\mathrm{N}-\mathrm{Mg}(\mathrm{r}=0.68, \mathrm{P}<0.01)$. The number of relationships of these elements decreased in the rest of the groups. The negative nature of the associations of $\mathrm{K}$ in legumes should be noted $(\mathrm{K}-\mathrm{Zn}, \mathrm{K}-\mathrm{Cu}$, and $\mathrm{K}-\mathrm{Na}$ ). This aspect of $\mathrm{K}$ is in accordance with that found by Kidambi (15) for two types of cultivated legumes and by Garcia (8) for species from seminatural communities.

For herbage, and specifically for $\mathrm{Ca}$, the only relationships which were not significant $(\mathrm{P}>0.05)$ are $\mathrm{Ca}-\mathrm{Na}$ and $\mathrm{Ca}-\mathrm{Fe}$. They are significant, however, in grasses, legumes, and other families.

In the four groups considered, $\mathrm{Zn}$ was the micronutrient showing the greatest number of associations. Manganese had fewer relationships, and in legumes, Mn concentration was not correlated with that of any element.

Effect of Topographical Position: On differentiating the upper and lower zones of slopes, within each group (grasses, legumes, other families, and herbage), the number of relationships between nutrients as well as the level of significance decreases with respect to consideration of the low and high zones together. This is manifested most notably in legumes and "others".

Only the relationship between $\mathrm{Ca}-\mathrm{Mg}$ is significant in all cases with correlation coefficients between $\mathrm{r}=0.38, \mathrm{P}<0.05$ (in other families for the high zone), and $\mathrm{r}$ $=0.73, \mathrm{P}<0.01$ (in legumes for the lower zone).

In grasses and herbage for the low part, the bioelements interact with each other a similar number of times, maintaining some relationships. This could be due to the marked predominance of grasses over other groups in this zone, and thus, the similarity of relationships between herbage and the family of grasses.

Likewise, the greater contribution in dry matter of other families seems to affect the grass for the upper zone of the slope, although its effect is less prominent.

\section{ACKNOWLEDGEMENTS}

This work was supported by the European Economic Community (Agriculture, Contracts 60.110A and 8001-ct90-0021). The authors are grateful to L. Garcia, J.C. Estevez, M. Hernandez, and E. Rodriguez for their assistance. 


\section{REFERENCES:}

1. Ammerman, C.B. and Goodrich, R.D. 1983. Advances in mineral nutrition in ruminants. J. Anim. Sci. 57(2):519-533.

2. Bates, T.E. 1972. Factors affecting critical nutrient concentrations in plants and their evaluation: a review. Soil Sci. 112(2):116-130.

3. Corona, E.P., Garcia, L., Garcia, A., Vazquez de Aldana, B.R. y Garcia, B. 1991. Produccion de pastizales en zonas semiaridas segun un gradiente topografico. XXXI Reunion Cientifica de la SEEP, Murcia, pp.304-309.

4. Drysdale, R.A., Devlin, T.J., Lillie, L.E., Fletcher, W.K. and Clark, K.W. 1981. Nutrient concentration in grass and legume forages of Northwestern Manitoba. Can. J. Anim. Sci. 60:991-1002.

5. Duque Macias, F. 1971. Determinacion conjunta de $\mathrm{P}, \mathrm{K}, \mathrm{Ca}, \mathrm{Mg}, \mathrm{Fe}, \mathrm{Mn}$, $\mathrm{Cu}$, y Zn en plantas. An. Edafol. Agrobiol. 30:207-229.

6. Fleming, G.A. 1973. Mineral composition of herbage, pp. 529-566. IN: G.W. Butler and R.W. Bailey (eds). Chemistry and Biochemistry of Herbage. Vol. 1. Academic Press, Inc., London.

7. Forbes, J.C. and Gelman, A.L. 1981. Copper and other minerals in herbage species and varieties on copper-deficient soils. Grass Forage Sci. 36:25-30.

8. Garcia,B., Valdes, A., Garcia, A. and Gomez, J.M. 1980. Relations between mineral elements concentrations in herbage plants of natural communities growing in the semi-arid area of Salamanca. Agrochimica XXIV(1):59-68.

9. Garcia, R., Moro, A., Calleja, A. y Suarez, A. 1984. Estudio de las relaciones entre elementos minerales en el suelo y la planta. An. Fac. Vet. Leon. 30:169-177.

10. Garcia Ciudad, A., Garcia Criado, B., and Montalvo, M.I. 1984. Seasonal variations in mineral composition of pastures in a semiarid zone of Spain, pp.397-401. IN: H. Riley and A.O. Skjelvag (eds.) The Impact of Climate on Grass Production and Quality. Proceedings 10th Gen. Meet. Eur. Grassld. Fed., As, Norway.

11. Garten, T.C. 1976. Correlations between concentrations of elements in plants. Nature 261:686-689.

12. Gomez, J.M. and Hoyos, C. de. 1982. Correlaciones entre bioelementos: estudio realizado en Trifolium subterraneum L. y Avena sativa L. An. Edafol. Agrobiol. 41(1/2):321-334.

13. Grunes, D.L. and Welch, R.M. 1989. Plant contents of magnesium, calcium and potasium in relation to rumiant nutrition. J. Anim. Sci. 67:3485-3494. 
14. Jones, D.I.H. and Thomas, T.A. 1987. Minerals in pastures and supplements, pp. 145-153. IN: R.W. Snaydon (ed.) Ecosystems of the World, 17B: Managed Grasslands. Elsevier, Amsterdam

15. Kidambi, S.P., Matches, A.G. and Bolger, T.P. 1990. Mineral concentrations in alfalfa and sainfoin as influenced by soil moisture level. Agron. J. 82:229-236.

16. Lamand, M. 1989. Zinc deficiency in rumiants, pp 64-70. IN: Proceedings International Meeting on Recent Progress Mineral Nutrition and Mineral Requirements in Rumiants, 1989. Hire Showado Insatsu, Kyoto, Japan.

17. Loneragan, J.F. 1975. The availability and absorption of trace elements in soil-plant systems and their relation to movement and concentrations of trace elements in plants, pp. 109-134. IN: D.J.D. Nicholas and E.R. Eagan (eds.) Trace Elements in Soil-Plant-Animal Systems. Academic Press, New York, NY.

18. Mayland, H.F. and Wilkinson, S.R. 1989. Soil factors affecting magnesium availability in plant-animal systems: A review. J. Anim. Sci. 67:3437-3444.

19. McDowell, L.R. 1985. Calcium, Phosphorus and Fluorine, pp. 189-212. IN: L. R. McDowell (ed.) Nutrition of Grazing Rumiants in Warm Climates. Academic Press, Inc., Boca Raton, FL.

20. Price, J. 1989. The nutritive value of grass in relation to mineral deficiencies and imbalances in the rumiant. The Fertiliser Soc. of London. Proc. No. 289. Peterborough, United Kingdom.

21. Reid, R.L. and Horvath, D.J. 1980. Soil chemistry and mineral problems in farm livestock. A review. Anim. Feed Sci. Technol. 5:95-169.

22. Whitehead, D.C. 1966. Nutrient minerals in grassland herbage. Mimeo. Publ. No. 1, Commonwealth Bureau Pasture and Field Crops, Hurley, Berkshire, England. 